\title{
The Connotation and Cultivation of Core Competence of Higher Vocational Colleges
}

\author{
Zhi-Kun HUANG* \\ Department of Computer, Wuhan polytechnic, Wuhan 430074, China \\ 275016483@qq.com \\ ${ }^{*}$ Corresponding author
}

Keywords: Core competitiveness, Education concept, Training mode, Double division faculty.

\begin{abstract}
The core competitiveness of higher vocational colleges is the driving force for the further development of vocational colleges. This paper describes the core competence of higher vocational colleges and the way to train the core competence of higher vocational colleges.
\end{abstract}

\section{The Connotation of Core Competence}

The core competitiveness is the essence of higher vocational colleges in higher vocational colleges to provide high-quality education in the process of long-term development of a product or service as the goal, with advanced education idea and technology as the core, on elements such as resources, capabilities, and knowledge on the basis of the integration, through continuous reform and innovation and make the school internal form of the general competitiveness of ascension for the school development with a sustainable competitive advantage of the unique core competencies. It mainly includes advanced education concept, unique advantages of running a school, optimization of talent training mode, double division faculty.

\section{The Connotation of the Characteristics of Running a School}

\section{Advanced Education Concept}

Teaching concept refers to the operators' perception of school orientation and function after running a school is a school practice and the accumulation of passing on the history of the school, and reflects the school to the real thinking and outlook for the future of spiritual culture, is the school's most valuable intangible assets. It not only leads the school thought, guide the direction of the school, the school behavior, reflect the unique charm of the school, and penetration in the ideology of the school community members, internalized as a kind of spiritual strength and goals, and gradually formed the school distinct personality characteristics.

\section{Unique Advantages of Running a School}

Characteristics of higher vocational education professional pertinence, directional, determines the direction of higher vocational colleges and professional Settings must be different from ordinary colleges and universities and other higher vocational colleges, so is better than that of other colleges and universities should actively construction series professional brand, establish a sound quality assurance system, provide the right between supply and demand of outstanding graduates, efforts to form a unique advantage and competitive advantage.

\section{Optimization of Talent Training Mode}

Personnel training mode is a school under the guidance of advanced education idea, talent training process and the operation mechanism of organic combination. Personnel training mode in higher vocational colleges should highlight the "people-oriented", in order to improve the employment rate as the basic starting point, we will do our best to help the combination of "teaching, learning and doing", and strive to achieve the "teaching process" in the "working process" implementation services for the purpose of the regional economic development. Personnel 
training mode in higher vocational colleges should highlight the "people-oriented", in order to improve the employment rate as the basic starting point, we will do our best to help the combination of "teaching, learning and doing", and strive to achieve the "teaching process" in the "working process" implementation services for the purpose of the regional economic development.

\section{The Faculty of Double Division Quality}

"Double teacher" teacher refers to a teacher who has both the teacher's qualification and professional qualification and is engaged in professional education. As the characteristic and focus of the construction of education teachers in higher vocational colleges, teachers are not only technicians but also teachers, and double division is an important index for the core competence of higher vocational colleges.

\section{The Choice of the Way to Cultivate the Characteristics of Running School in Higher Vocational Colleges}

\section{Advanced Educational Philosophy}

The advanced educational philosophy is the most important index of the core competitiveness of higher vocational colleges. To serve for the purpose, employment as the guidance, establish and practice the advanced educational philosophy and scientific positioning of running school, the innovation of higher vocational education personnel training mode, the implementation of the product strategy, to create a unique brand of higher vocational education, highlight the characteristics of higher vocational education, strengthen the student's quality education and ability training, improve the quality of the education quality of teaching and talent training and employment rate and employment quality, won the trust of the students, parents and social, set up first-class level of higher vocational education brand image.

\section{Unique Advantages of Running a School}

The unique advantages of running a school are mainly reflected in the professional and curriculum system. Higher vocational colleges should fully combined with its own history and development achievements for running, from the service area, the need of local economic and social development, further optimize the integration of all kinds of education resources of science, as much as possible to build their own professional, focus on professional characteristic.

Identify professional positioning, identify professional construction goals, and make key professional construction consistent with the overall construction plan of the school. Strive to create excellent courses and excellent practice base, strive to make the school brand characteristics, professional and industry enterprises to provide quality services to achieve win-win situation, and to promote the development of school series related group, make the school running level and education level to a new level.

\section{Optimization of Talent Training Mode}

The advantage of higher vocational colleges is relying on the industry, striving to realize the "alternation of industry and learning", and actively constructing "the factory in the university" and "the school in the factory". To actively select potential industry with big, good market prospects for the effective support of running school, give full play to the role of the university-enterprise cooperation platform, and actively to industry, the enterprise technology advantage into school education teaching, further optimization and integration of educational resources. In higher vocational colleges should be on the basis of comprehensive investigation and study, clear its own strengths, weaknesses, and to the innovation strives for the survival and development through characteristic, to the country and the world vocational education development direction, development prospect of development strategies, development priorities, such as for prospective studies, scientific selection is conform to the reality and the future demand and has its own characteristics of several subject or a group as the main direction, as the school plays an important role in the building of the core competence. Personnel training mode is a school for the students the 
knowledge, ability and quality structure of the building and implementing the structure of the way, fundamentally defines talents training target and focus reflects the education ideas and concepts. The innovation of the personnel training mode should actively carry out combined with productive labor and social practice mode of learning, the work-integrated learning as an important point of the higher vocational education personnel training mode reform. We should pay more attention to the consistency between the students' learning and the actual work, and explore the teaching mode which is conducive to enhancing the students' ability, such as the alternation of work, the task drive, the project orientation, and the on-the-job internship.

\section{We Will Strengthen the "Double Division" Team Building}

Higher vocational colleges should start with teaching team construction as the center, strengthening the professional leaders, backbone teachers, subject teacher, teaching training, support them to participate in various forms of learning study, improve their ability of vocational education and social services. Followed by strengthening enterprise technical expert introduction, fully absorb the industry, enterprises and institutions, senior engineer, technician, senior executives and other personnel with special skills as full-time and part-time teachers. Again to focus on strengthening the construction of teacher's ethics, the ethics as the basis of employment, evaluation and rewards and punishments and promotion, make "career advancement opportunities to attract and retain talented people, system recognition" from passive to active.

To achieve the training objectives of higher vocational education, we must implement the open school-running, university-enterprise cooperation, take measures to increase corporate has rich experience in professional teaching experts, the industry enterprises directly involved in the process of talent training, through the combination of ways to make a lot of good professional ethics, innovation spirit and practice ability of high-quality skilled personnel. The goal of teaching staff in higher vocational colleges is a "double division" teacher team which is integrated with part-time teachers from industry enterprises. A good vocational teachers from ordinary teachers, the backbone teachers, professional leaders, as well as ordinary teacher and technical personnel, technical experts, senior technicians, industry leader of two tower structure.

\section{Summary}

The core competitiveness of higher vocational colleges is a reflection of the unique and continuous competitive advantage of higher vocational colleges. It has characteristics that cannot be imitated or replaced by competitors. Therefore, the construction of core competitiveness of higher vocational colleges is a complex system engineering. Given the limited resources and the development of history in the college of precipitation, higher vocational colleges should seize stages or one dimension of competitive advantage, and on this basis, gradually build its own core competitiveness, casting the brand of higher vocational colleges.

\section{References}

[1] Wang Qian-xin,Lu Hong-xue. Higher vocational education[M].Shantou: Shantou university press,2003.

[2] Chen Yu-hua. On the concept of running a school in the new era[J]. Chinese high education research.2004(6).

[4] Liu Lan-ming. Higher vocational technology education school characteristics research[M].Wuhan. Published by huazhong university of science and technology.

[5] Sun Zhi-nan. On the construction of core competitiveness of demonstration vocational colleges[J]. Education and Vocation.2009. 